\title{
Indigenous knowledge: From local to global
}

\author{
This article belongs to Ambio's 50th Anniversary Collection. Theme: Biodiversity \\ Conservation
}

\author{
Madhav Gadgil, Fikret Berkes, Carl Folke
}

Published online: 10 February 2021

When the three of us (Gadgil, Berkes and Folke) started working together in 1992 in Stockholm at the Beijer Institute of Ecological Economics, we discovered a common interest in the relevance of indigenous knowledge for biodiversity conservation. At the time, there were publications related to traditional ecological knowledge in human ecology, cultural anthropology and ethnobiology. But no literature existed on biodiversity conservation and indigenous peoples with a global perspective. We sought to address that gap with a short paper in Ambio on biodiversity: "enhancement activities of indigenous peoples, the knowledge base underlying it, as well as linkages to practices dealing with ecosystems and related belief systems" (Gadgil et al. 1993, pp. 151-152).

We had no idea that "indigenous knowledge for biodiversity conservation" would become a major topic in international biodiversity conservation, with contributions such as those by Garnett et al. (2018), Tengö et al. (2014, 2017) and the Intergovernmental Science-Policy Platform on Biodiversity and Ecosystem Services (IPBES) (Díaz et al. 2018) which has a Task Force on Indigenous and Local Knowledge Systems (Hill et al. 2020). Indigenous knowledge for biodiversity conservation is as relevant today as it was in 1993, except that its significance has been recognised by a larger group of scholars, practitioners and even policy-makers. Indigenous people themselves appreciated its importance all along. This wider recognition of indigenous knowledge is a positive development in today's difficult world.

The world seems to be poised on a tipping point today. On this hot and angry earth, business as usual is obviously landing us in ever greater difficulties, and there is an increasing awareness that we might have to change the way that economies over most of the world have been marching. As Raymond Dasmann (1976) suggested, the currently operative economies have primarily benefited those he terms as "biosphere people" at the cost of "ecosystem people". Biosphere people have the political and economic power to avail themselves of the resources of the entire global biosphere, while 'ecosystem people' depend largely on natural resources in their immediate vicinity. Most citizens of Europe and their descendants in Neo-Europes of North and South Americas, Australia and New Zealand and some African countries like South Africa, along with the wealthier classes in countries of the remaining world, such as India belong to the category of the biosphere people.

Yet a large proportion of people of India and most of southeast Asia, Africa and South America and some of the original inhabitants of northern reaches of North America, such as the Cree people and of northern reaches of Europe such as Saami people, are ecosystem people dependent for their well-being on a healthy base of natural resources of their own surroundings. An increasingly large proportion of the ecosystem people are suffering from a destruction of the base of natural resources that sustain their livelihoods, such as fisherfolk who have become victims of pollution and are forced to migrate and join the gangs of construction labour. One may term them as ecological refugees.

Everywhere the economic forces are driving destruction of nature that is today on retreat. Where it is being saved it is through striving of the local communities motivated to maintain it, whether it be in India with people given rights over community forest resources or in Switzerland with its canton forests. However, urban communities cut off from people at grassroots are under a misconception that only state efforts can save the natural resources and this misconception informs programmes of organisations such as World Wildlife Fund as well. If we wish to pacify the angry earth, then the wisdom, the knowledge, the 
traditions, the practices of the ecosystem people may hold important clues.

Their knowledge is partly based on valid observations along with beliefs with no basis in reality. Yet, they possess valuable understanding of the working of the natural world acquired over generations, along with that acquired in their day-to-day pursuit of livelihoods. The experience of a group of Bangalore-based ecologists investigating the fate of wild gooseberry Phyllanthus emblica populations on the Biligiriranga Temple hills provides an interesting case history. The scientific hypothesis was that the regeneration is governed by commercial collection of fruit, and that recent low levels of regeneration were due to excessive harvests. So, they laid out experiments to test this hypothesis. The local Soliga people told them that in their experience regeneration was primarily influenced by control of forest fires. The experimental results eventually showed that Soligas were indeed right.

\section{INDIA'S SACRED GROVES}

My love affair with sacred groves, India's treasure troves of biodiversity, began in August 1971 a month after I returned from Harvard with a Ph.D. in Biology. I was delighted to meet my former botany teacher, V. D. Vartak and we set out on a field trip. As we drove along the hills of the northern Western Ghats, I felt increasingly depressed at the sight of the barren hills covered with tropical rain forest until the early 1960s. Suddenly we saw a 5-ha patch of luxuriant evergreen forest, within which towered four trees of dhup Canarium strictum a species characteristic of the southern Western Ghats, $500 \mathrm{~km}$ away.

Vartak explained that this grove had survived because it was sacred to a local deity and that other such remnants of primeval vegetation were scattered all over the Western Ghats. On returning, I read up on sacred groves. Though mentioned frequently in literature on folklore and cultural and religious beliefs, I found no systematic investigations of the phenomenon, let alone studies from an ecological or social science perspective. The reigning hypothesis among conservationists was that they represented lingering elements of nature worship prevalent in primitive societies; they had no secular functions but persisted because of superstition.

That hypothesis implied that sacred groves should be concentrated at religious sites like mountain peaks or sources of rivers. It seemed more plausible to me that, whereas sacred groves may receive protection through religious beliefs, the system is grounded in secular benefits, such as securing fresh water sources. According to this hypothesis, sacred groves would not be restricted to particular kinds of habitats but would be distributed throughout the entire range of habitat types. So, we decided to collect primary field data to test this prediction.

One of Vartak's old classmates, now Deputy Chief of State Forest Department, suggested that hills of Velhe (near the city of Pune in western India), was an appropriate study site and arranged for a Forest Guard to accompany us. We went across the lake in launch along with the guard and landed at the foot of the hills on which lay the cluster of villages of our interest. It was a fascinating experience: trekking up to villages with significant patches of sacred groves, making notes on their size, botanical composition, animal life, topographic location, settlements and cultivation and talking to people about their traditions, beliefs and ecological knowledge. The villagers readily granted our request to share their meals and shelter for the night.

The moment we reached a village our Forest Guard guide vanished from sight only to appear the next morning. We asked our hosts what he was up to. They said he would go to another village where he would demand a chicken to be cooked for his dinner, enjoy the meal washed down with a bottle of country liquor supplied by the villagers and sleep soundly till the next morning.

As we chatted with the villagers at night the history of the hills unfolded before our eyes, a history very different from the prevalent urban misconceptions. These blamed the short-sightedness, greed and improvidence of the villagers for the denudation of the catchment of the series of dams under construction on the Western Ghats, despite honest attempts of the irrigation engineers and forest officials. In reality, the villagers said that they left fully intact valuable trees such as mango Mangifera indica, wild gooseberry and myrobolan Terminalia chebula while clearing the plots for their 15-year cycle shifting cultivation agriculture. As soon as roads reached these remote hills that had never been the part of any cash economy, the engineers accompanied by timber and coal merchants approached and told them that they would have to leave and be given land for cultivation somewhere else. So, they might as well cash all the trees on their land, and they ended up selling huge mango trees for as little as half a rupee. In a couple of years, the area had become largely treeless. The corrupt forest department officials also liquidated much of the reserve forest in collusion with the timber merchants.

Apart from these novel insights into the operation of the social, political and economic forces in the society, our data revealed that people perceived and valued the ecosystem services that the sacred groves offered and were continuing to protect them because they wished to avail themselves of these benefits. Most groves protected water sources; many sheltered valuable medicinal plants, while larger ones served as refugia for animals hunted outside the sacred groves. Mangaon village had one of the largest 
groves and the villagers reported that it sheltered a breeding population of barking deer Muntiacus muntjak, which they could hunt outside the grove from time to time.

Six months later, I received a letter from people of Gani, a village on the western slopes of northern Western Ghats, who were shocked by Forest Department marking trees in their sacred grove for felling. I reached the village post haste and saw their grove of fifteen hectares, all of it in its primeval state: there had never been any felling in the grove within human memory. All the surrounding region had been completely deforested, and people had no source of dead wood or of leaf litter for preparing the paddy fields except for the grove. Moreover, apart from a village well, the only perennial water source for the cattle or for the people working in the field was a spring in the grove. I spent a couple of days with them, documenting these facts and then met the Head of Forestry in the state. He had little interest in any details but remarked that while he would grant the request since I pleaded for the villagers, but such groves were nothing but worthless "stands of overmatured timber". This vividly brought to me how people at the grassroots valued ecosystem services and how the bureaucracy trashed such services. Evidently, if we wish to nurse our planet back to a healthier state and continue to preserve its heritage of biodiversity, we must begin to respect the ecosystem people on our planet and draw upon their knowledge.

\section{CONCLUSIONS}

These interests in folk conservation practices led to my being invited to join the Biodiversity Programme at Beijer Institute of the Royal Swedish Academy of Sciences, and later, the project on Linking Social and Ecological Systems also at Beijer. Here I worked with Fikret Berkes and Carl Folke, distinguished scholars in the broad area of indigenous knowledge for biodiversity conservation, and we have collaborated on several papers over the years. It is only an accident that I was the first author on this particular paper. Fikret and Carl have contributed complementary content from their studies of indigenous peoples, such as the Cree people and Saami people, agricultural and aquacultural systems and from the broader area of integrated socialecological systems.

Based on our experience in these areas, and encouraged by the knowledge-practice-belief systems of ecosystem people, we wrote our short and modest article on indigenous knowledge for biodiversity conservation (Gadgil et al. 1993). Today, it is truly inspiring to observe the widespread recognition and appreciation-in science, management, and international conventions - of the role of ecosystem people in stewardship of biodiversity, ecosystem services and nature's contribution to people. But recognition is not enough: still much needs to be done to implement such ideas. Indigenous stewardship of biodiversity is urgently needed since it provides the foundation for livelihoods and well-being for the still growing human population confronted with climate change and other environmental challenges.

\section{REFERENCES}

Dasmann, R. 1976. Future primitive: Ecosystem people versus biosphere people. Coevolution Quarterly 11: 26-31.

Díaz, S.U., M. Pascual, B. Stenseke, R.T. Martín-López, Z. Watson, R. Molnár, K.M.A.Chan Hill, et al. 2018. Assessing nature's contributions to people. Science 359: 270-272.

Gadgil, M., F. Berkes, and C. Folke. 1993. Indigenous knowledge for biodiversity conservation. Ambio 22: 151-156.

Garnett, S.T., N.D. Burgess, J.E. Fa, Á. Fernández-Llamazares, Z. Molnár, C.J. Robinson, J.E.M. Watson, K.K. Zander, et al. 2018. A spatial overview of the global importance of Indigenous lands for conservation. Nature Sustainability 1: 369-374.

Hill, R., C. Adem, W.V. Alangui, Z. Molnár, Y. AumeeruddyThomas, P. Bridgewater, M. Tengö, R. Thaman, et al. 2020. Working with indigenous, local and scientific knowledge in assessments of nature and nature's linkages with people. Current Opinion in Environmental Sustainability 43: 8-20.

Tengö, M., E.S. Brondizio, T. Elmqvist, P. Malmer, and M. Spierenburg. 2014. Connecting diverse knowledge systems for enhanced ecosystem governance: The multiple evidence base approach. Ambio 43: 579-591.

Tengö, M., R. Hill, P. Malmer, C.M. Raymond, M. Spierenburg, F. Danielsen, T. Elmqvist, and C. Folke. 2017. Weaving knowledge systems in IPBES, CBD and beyond-Lessons learned for sustainability. Current Opinion in Environmental Sustainability 26-27: 17-25.

Publisher's Note Springer Nature remains neutral with regard to jurisdictional claims in published maps and institutional affiliations.

Madhav Gadgil ( $\square)$

Address: The Beijer Institute of Ecological Economics, Stockholm, Sweden.

e-mail: madhav.gadgil@gmail.com

\section{Fikret Berkes}

Address: Natural Resources Institute, University of Manitoba, 70 Dysart Road, Winnipeg, MB R3T 2N2, Canada.

e-mail: fikret.berkes@umanitoba.ca

\section{Carl Folke}

Address: The Beijer Institute of Ecological Economics, Stockholm, Sweden.

e-mail: carl.folke@beijer.kva.se 